Jurnal Health Sains: p-ISSN: 2723-4339 e-ISSN: 2548-1398

Vol. 3, No. 1, Januari 2022

\title{
BURNOUT DAN PRODUKTIVITAS KERJA TENAGA KEPERAWATAN PADA MASA PANDEMI COVID-19 DI RS MEDIKA BSD
}

\author{
Yanna Dwi Saptarani, Agusdini Banun Saptaningsih, R. Fresly Hutapea \\ Universitas Esa Unggul, Jakarta, Indonesia \\ Email: yannasaptarani@gmail.com,dini_banun_dini@yahoo.com, fresleyhutapea@yahoo.com
}

\begin{tabular}{|c|c|}
\hline INFO ARTIKEL & ABSTRAK \\
\hline $\begin{array}{l}\text { Diterima } \\
5 \text { Januari } 2022 \\
\text { Direvisi } \\
\text { 15 Januari } 2022 \\
\text { Disetujui } \\
\text { 25 Januari 2022 } \\
\text { Kata Kunci: } \\
\text { burnout; } \\
\text { produktivitas kerja; } \\
\text { beban kerja; } \\
\text { dukungan sosial; } \\
\text { pandemi COVID-19 }\end{array}$ & $\begin{array}{l}\text { Tujuan penelitian ini, untuk menganalisis pengaruh beban kerja dan } \\
\text { dukungan sosial terhadap produktivitas kerja perawat pada masa } \\
\text { Pandemi COVID }-19 \text {, dengan burnout sebagai variable intervening di RS } \\
\text { Medika BSD. Penelitian ini menggunakan metode kuantitatif, desain ex- } \\
\text { post facto, dengan survei serta path analysis. Populasinya adalah seluruh } \\
\text { perawat dengan sample berjumlah } 100 \text { orang. Hasil pengujian } \\
\text { menunjukan, Beban Kerja ( } \mathrm{p}=0,108 \text { ); dan dukungan sosial ( } \mathrm{p}=0,199) \\
\text { terhadap produktivitas, keduanya p value }>\text { alpha } 0,5 \text {. Sedangkan } \\
\text { burnout terhadap: produktivitas ( } \mathrm{p}=0,000 \text { ), beban kerja ( } \mathrm{p}=0,001 \text { ); dan } \\
\text { dukungan sosial ( } \mathrm{p}=0,000 \text { ), artinya ketiganya memiliki p value } \leq 0,05 \text {. } \\
\text { Pengaruh tidak langsung yang dimediasi oleh burnout menunjukkan nilai } \\
\text { t hitung > t tabel (uji Sobel). Penelitian ini menunjukan bahwa burnout } \\
\text { berpengaruh langsung terhadap produktivitas kerja, serta terdapat } \\
\text { pengaruh positif dan signifikan beban kerja dan dukungan sosial } \\
\text { terhadap produktivitas kerja melalui burnout sebagai variable } \\
\text { intervening. Implikasi manajerial yang dihasilkan dari penelitian ini } \\
\text { berupa sistem pengaturan beban kerja, rolling staff untuk mengurangi } \\
\text { kejenuhan, sistem antrian yang dapat mengurangi kepadatan frekwensi } \\
\text { datangnya pekerjaan, sistem levelink perawat sesuai kompetensinya. } \\
\text { Untuk dukungan sosial dilakukan melalui sistem kerja secara teamwork, } \\
\text { peningkatan komunikasi efektif antar staf, sistem pengembangan } \\
\text { Sumber Daya Manusia melalui pelatihan dan Capacity Building untuk } \\
\text { meningkatkan kemampuan, motivasi dan pengembangan diri, diterapkan } \\
\text { pula sistem apresisasi terhadap peningkatan kinerja perawat. Untuk } \\
\text { menghindari kondisi burnout dapat dilakukan Program Kesehatan } \\
\text { Mental pegawai, mulai dari pemeriksaan mental, self help content } \\
\text { sampai konseling yang dilakukan oleh tenaga profesional. Semua hal } \\
\text { tersebut semata-mata untuk tetap dapat mempertahankan produktifitas } \\
\text { kerja perawat. }\end{array}$ \\
\hline
\end{tabular}

\section{ABSTRACT}

The purpose of this study was to analyze the effect of workload and social support on the work productivity of nurses during the COVID-19 pandemic, with burnout as an intervening variable at Medika BSD Hospital. This study uses quantitative methods, ex-post facto design, surveys and path analysis. The population is all nurses with a sample of 100 people. The test results show, Workload $(p=0.108)$; and social support ( $p=0.199)$ on productivity, both $p$ value > alpha 0.5. While burnout on: productivity $(p=0.000)$, workload $(p=0.001)$; and social support $(p=0.000)$, meaning that all three have $p$ value 0.05 . The indirect effect mediated by burnout shows the value of $t$ count $>t$ table

$\begin{array}{ll}\text { How to cite: } & \text { Saptarani. et.al (2022) Burnout dan Produktivitas Kerja Tenaga Keperawatan pada Masa Pandemi } \\ & \text { Covid-19 di RS Medika BSD. Jurnal Health Sains 3(1). https://doi.org/10.46799/jhs.v3i1.400 } \\ \text { E-ISSN: } & 2723-6927 \\ \text { Published by: } & \text { Ridwan Institute }\end{array}$


(Sobel test). This study shows that burnout has a direct effect on work productivity, and there is a positive and significant influence on workload and social support on work productivity through burnout as an intervening variable. The managerial implications resulting from this research are in the form of a workload management system, rolling staff to reduce boredom, a queuing system that can reduce the density of the frequency of work arrivals, a nurse levelink system according to their competence. For social support, it is carried out through a teamwork system, increasing effective communication between staff, developing a system for developing human resources through training and capacity

Keywords:

burnouts; work productivity; workload; social support; COVID-19 pandemic building to improve abilities, motivation and self-development, as well as an appreciation system for improving nurse performance. To avoid burnout conditions, mental health programs can be carried out for employees, ranging from mental examinations, self help content to counseling carried out by professionals. All of these things are solely to maintain the productivity of nurses' work.

\section{Pendahuluan}

Corona Virus Disease (COVID-19)

telah menjadi pandemi global semenjak diumumkan oleh WHO pada tanggal 11 Maret 2020 oleh Direktur Jenderal Organisasi Kesehatan Dunia (WHO) dr. Tedros Adhanom Ghebreyesus. Dalam hitungan bulan saja, virus ini sudah menyebar ke seluruh negara di dunia (Dong \& Bouey, 2020). COVID-19 pertama kali muncul di kawasan Wuhan, Provinsi Hubei, China pada akhir tahun 2019 dengan perkembangan yang cepat dan tidak terkontrol ke seluruh dunia, saat ini tercatat sudah lebih 213 negara yang terkonfirmasi terinfeksi COVID-19 dengan jumlah korban sampai tanggal 5 Juni 2021 sebanyak 172.242.495 orang terkonfirmasi positif dan korban meninggal tercatat sebanyak 3.709.397 orang (Organization, 2019).

Badan Nasional Penanggulangan Bencana (BNPB), melalui Keputusan No. 9 A, 2020 menetapkan Status Keadaan Tertentu Darurat Bencana Wabah Penyakit akibat Virus Corona di Indonesia, yang kemudian diperpanjang melalui Keputusan No. 13 A, 2020 (Yulianto et al., 2021). Di Indonesia kasus COVID-19 pertama muncul pada tanggal 2 Maret 2020. Sampai 5 Juni 2021, Indonesia telah melaporkan 1.850.206 kasus positif menempati peringkat pertama terbanyak di Asia Tenggara. Dalam hal angka kematian, Indonesia menempati peringkat ketiga tertinggi di Asia dengan 51.449 kematian. Jakarta merupakan daerah yang terbanyak pasien COVID-19, dikuti beberapa provinsi lainnya, seperti Jawa Barat, Jawa Tengah, Jawa Timur, Sumatera Barat, Sumatera Utara, Riau dan Bali. Intinya, COVID-19, telah menyebar secara luas dan cepat di seluruh dunia termasuk di Indonesia (Papdi et al., 2008).

Perawat merupakan salah satu pekerjaan dengan tuntutan kerja yang tinggi (Maharja, 2015). Tekanan yang dialami dapat berakibat pada menurunnya performansi kerja perawat. Ketika tuntutan kerja tinggi maka akan sulit bagi seorang pekerja menyalurkan energi secara efisien, karena dibutuhkan usaha yang lebih besar sehingga menyebabkan penurunan performansi (Bakker et al., 2014). Pentingnya produktivitas kerja bagi perawat sebagai bahan evaluasi dan perbaikan secara terus menerus bagi seluruh komponen rumah sakit, serta peningkatan mutu hasil kerja rumah sakit. Dampak dari rumah sakit yang memiliki produktivitas rendah akan mengakibatkan turunnya jumlah pelanggan, karena rendahnya kualitas pelayanan yang dihasilkan sehingga pelanggan akan berpindah pada organisasi lain yang memiliki 
produktivitas kerja yang tinggi dan kualitas pelayanan yang bermutu (Siagian, 2001).

Peningkatan kualitas pelayanan rumah sakit harus disertai dengan peningkatan pelayanan keperawatan, salah satunya melalui upaya peningkatan kinerja perawat (Lenny Hasan \& Febriani, 2016). Menurut (Maslach \& Jackson, 1981) burnout berhubungan dengan pekerjaan yang terkait dengan klien. Bekerja melayani orang lain membutuhkan dan menghabiskan banyak energy karena harus bersikap sabar dan memahami masalah orang lain (Pardo et al., 2014).

Perawat yang diberi beban kerja berlebihan dapat berdampak kepada penurunan tingkat kesehatan, motivasi kerja, kualitas pelayanan keperawatan dan kegagalan melakukan tindakan pertolongan terhadap pasien serta memungkinkan terjadinya kelalaian atau bahkan kematian pada pasien. Selain itu menurut (Aini \& Purwaningsih, 2013) akibat negatif dari meningkatnya beban kerja adalah kemungkinan timbul emosi perawat yang tidak sesuai dengan harapan pasien dan berpengaruh terhadap kualitas pelayanan keperawatan. (Schultz \& Schultz, 2020) menyatakan beban kerja adalah terlalu banyak pekerjaan pada waktu yang tersedia atau melakukan pekerjaan yang sulit untuk karyawan. Beban kerja yang berlebihan adalah sumber stress yang paling utama, 37\% terhadap ketidak puasan kerja, depresi, gejala psikosomatik, burnout, 30\%-50\% lingkungan kerja merupakan sumber stress. $16 \%$ perawat meninggalkan pekerjaan profesinya (Zahroh \& Suhartoyo, 2013)

Penelitian tentang beban kerja di Inggris menyatakan bahwa beban kerja memiliki hubungan yang signifikan berkaitan dengan kelelahan dan dapat mengakibatkan burnout. (Smith \& Smith, 2017). Terkait masalah Pandemi COVID-19 salah satu penelitian yang di lakukan pada 60 Negara oleh Morgantini et al, (2020) dengan judul "Factors contributing to healthcare professional burnout during the COVID-19 pandemic: A rapid turnaround global survey". Ditemukan bahwa: A total of 2,707 HCPs from 60 countries participated in this study. Fifty-one percent of Healthcare Professionals (HCPs) reported burnout. Burnout was associated with work impacting household, feeling pushed beyond training, exposure to COVID-19 patients, and making life prioritizing decisions. Adequate Personal Protective Equipment (PPE) was protective against burnout. Burnout was higher in highincome countries (HICs) compared to lowand middle-income countries (LMICs).

Penelitian (Hardiyono et al., 2020) dengan judul "Effect Covid-19: Burnout on nurse", menyatakan berdasarkan hasil tanggapan responden pada diketahui bahwa telah terjadi kelelahan pada perawat yang menangani pasien COVID-19 di rumah sakit. Seiring bertambahnya beban kerja akan berdampak pada stres kerja, namun dikarenakan masih kurangnya penelitian yaitu sulitnya mengumpulkan seluruh perawat yang menangani pasien COVID-19 karena perawat sangat sibuk merawat pasien sehingga detail hasil dari pokok bahasan yang akan dipelajari hanya dapat digeneralisasikan.

Penelitian yang dilakukan tim peneliti dari Program Studi Magister Kedokteran Kerja Fakultas Kedokteran Universitas Indonesia, menunjukkan fakta bahwa sebanyak $83 \%$ tenaga kesehatan di Indonesia telah mengalami burnout syndrome derajat sedang dan berat yang secara psikologis sudah berisiko mengganggu kualitas hidup dan produktivitas kerja dalam pelayanan kesehatan. Menurut Ketua Tim Peneliti Dr. dr. Dewi Soemarko, MS, SpOK, penelitian ini juga menemukan fakta bahwa Dokter Umum di Indonesia yang menjalankan Tugas Pelayanan Medis di garda terdepan selama Masa Pandemi COVID-19 memiliki risiko 2 (dua) kali lebih besar untuk mengalami burnout syndrome. Tingginya risiko menderita burnout syndrome akibat pajanan 
stres yang luar biasa berat di fasilitas kesehatan selama pandemik ini dapat mengakibatkan efek jangka panjang terhadap kualitas pelayanan medis karena para tenaga kesehatan ini bisa merasa depresi, kelelahan ekstrim bahkan merasa kurang kompeten dalam menjalankan tugas, dan ini tentu berdampak kurang baik bagi upaya kita memerangi COVID-19 (Humas, 2020)

Dari berbagai penelitian yang telah di paparkan sebelumnya diatas, Novelty atau unsur kebaruan yang merupakan temuan terbaru dari penelitian ini yaitu burnout yang memediasi pengaruh-pengaruh yang ditimbulkan dari beban kerja dan dukungan sosial terhadap produktivitas kerja perawat, sehingga penelitian ini dapat memberikan kontribusi untuk mengembangkan ilmu Sumber Daya Manusia (SDM) serta psikologis tenaga keperawatan dalam kaitannya dengan produktivitas kerja.

\section{Metode Penelitian}

Penelitian ini dilakukan dengan desain ex-post facto, dimana peneliti berusaha untuk meneliti sesuatu fakta yang telah terjadi di lapangan. Pendekatan yang digunakan dalam penelitian ini dilakukan secara kuantitatif (menghasilkan data-data berupa kumpulan angka). Penelitian ini juga menggunakan metode survei dan analisis jalur (path analysis).

Populasi target dan Populasi terjangkau pada penelitian ini yaitu Rumah Sakit Medika BSD. Populasinya adalah seluruh anggota bagian keperawatan di RS Medika BSD. Jumlah keseluruhan perawat yang terdata di bagian Human Resources Development (HRD) tahun 2021 berjumlah 107 orang.

Pemilihan sample, dilakukan dengan teknik non probability sampling, pemilihan samplenya menggunakan Metode Sampling jenuh dimana semua anggota populasi digunakan sebagai sampel. Cara tersebut dilakukan karena anggota populasi dianggap homogen dan jumlah unit sampling dalam populasi tidak terlalu besar. Selain itu pertimbangannya adalah dengan semakin besar jumlah sampel (semakin mendekati populasi) maka semakin kecil peluang kesalahan secara generalisasi.

Dalam penelitian ini teknik pengumpulan data dilakukan dengan metode sampling menggunakan kuesioner atau angket sebagai alat penelitian. Skala yang digunakan dalam penyusunan kuesioner ini menggunakan skala interval dengan menggunakan skala model Likert yang digunakan dalam peneltian ini merujuk pada lima alternative jawaban, yakni Sangat setuju atau sangat puas (5), setuju atau puas (4), Ragu-ragu (3), tidak setuju atau tidak puas (2) dan sangat tidak setuju atau sangat tidak puas (1).

Untuk mendapatkan hipotesis, pengujian dilakukan dengan menggunakan pendekatan Structural Equation Modeling (SEM) dan menggunakan software Partial Least Square (PLS). Pemilihan PLS didasarkan karena didalamnya terdapat 3 kegiatan secara bersamaan, yaitu pemeriksaan validitas dan reliabilitas instrumen (confirmatory factor analysis), pengujian model hubungan antara variabel (path analysis), dan mendapatkan model yang cocok untuk predeksi (analisis model struktural dan analisis regresi) (Ghozali, 2018). Evaluasi model PLS ini dilakukan untuk mengetahui validitas dan realibilitas yang menghubungkan indikator dengan variabel latennya.

Teknik analisis data

1. Metode Analisis data

- Analisis kualitatif $\rightarrow$ Dasar dari pendekatan teoritis dan penilaian logis, sebagai gambaran deskriptif tentang tanggapan responden pada kuesioner, kemudian dihubungkan dengan teori atau pendekatan-penekatan lain yang berkaitan. 
- Analisis index jawaban dengan menggunakan kriteria Three Box Methode.

- Analsis kuantitatif $\rightarrow$ Menggunakan path analisis

2. Metode Analisis Jalur (Path Analisis)

Pendekatan regresi untuk menguji variabel mediasi, dilakukan dengan prosedur Uji Sobel.

\section{Hasil dan Pembahasan}

\section{A. Deskripsi Data}

RS Medika BSD merupakan sebuah rumah sakit yang terletak di lokasi strategis dikawasan pemukiman yang sedang berkembang pesat di wilayah Tangerang Selatan. Dengan akses yang mudah di capai dan tepat berada di jalan utama, RS Medika BSD beralamat di Jl. Letnan Soetopo Kav Kom III A No.7, BSD City, Serpong 15330, Tangerang Selatan, Provinsi Banten. RS Medika BSD di pilih sebagai tempat penelitian, dengan beberapa pertimbangan diantaranya pada saat pandemi COVID-19 ini berlangsung, RS Medika BSD merupakan salah satu rumah sakit yang menerima perawatan pasien-pasien COVID-19, sehingga diharapkan dapat merepresentasikan kondisi sesuai dengan penelitian yang dilakukan.

Dari total 107 sampel/kuisioner yang disebarkan pada seluruh responden, didapatkan 100 kuisioner yang kembali untuk diolah dalam penelitian ini. Karakteristik responden berdasarkan jenis kelamin, diperoleh gambaran bahwa dari $83 \%$ responden mayoritas perempuan; sedangkan laki-laki sebanyak $17 \%$. Berdasarkan usia, diperoleh gambaran bahwa dari $61 \%$ responden mayoritas berumur 20 - 30 tahun; sebanyak $31 \%$ berumur 31 - 40 tahun; dan yang terendah berumur $41-50$ tahun sebanyak $8 \%$.
Karakteristik responden berdasarkan pendidikan terakhir, diperoleh gambaran bahwa dari $54 \%$ responden tertinggi adalah yang berpendidikan S1; sebanyak $24 \%$ berpendidikan Diploma; dan sebanyak $2 \%$ saja yang berpendidikan S2. Karakteristik responden berdasarkan pendapatan rata-rata perbulan, diperoleh gambaran bahwa dari $86 \%$ responden pendapatannya Rp. $3.000 .000-$ Rp. 5.000.000; dan sebanyak $14 \%$ pendapatannya Rp. $5.000 .000-$ Rp. 10.000.000. Untuk Karakteristik Unit Kerja, di Dominasi oleh Bagian/Unit Poliklinik Sebanyak 16\%, disusul oleh Unit Rawat Inap Isolasi sebanyak 15\%, Instalasi Rawat Inap dan Unit Hemodialisa masing-masing sejumlah $14 \%$, dan Instalasi Gawat Darurat (IGD) dengan perawat sejumlah $13 \%$, dan sisanya unitunit lainnya.

\section{B. Hasil Penelitian}

\section{Uji Validitas dan Reliabilitas}

Hasil uji validitas dalam PLS sesuai data:

\section{a. Loading Factor}

Pengukuran akan dianggap valid jika faktor pembebanan > 0,70 dan AVE > 0,50 untuk setiap variabel. Sehingga ada beberapa indikator yang tidak valid sebelumnya, peneliti kemudian melakukan proses eliminasi pada indikator yang tidak valid, hingga semua indikator valid dan akan memenuhi kriteria untuk selanjutnya uji validitas dan reliabilitas. Peneliti juga telah mengamati bagaimana penghapusan file indikator yang tidak valid akan mempengaruhi indikator lainnya. Faktor pembebanan kemudian direvisi kembali dari tes dan kemudian hasilnya di dapatkan model akhir pada Factor loading post test seperti pada gambar berikut ini: 


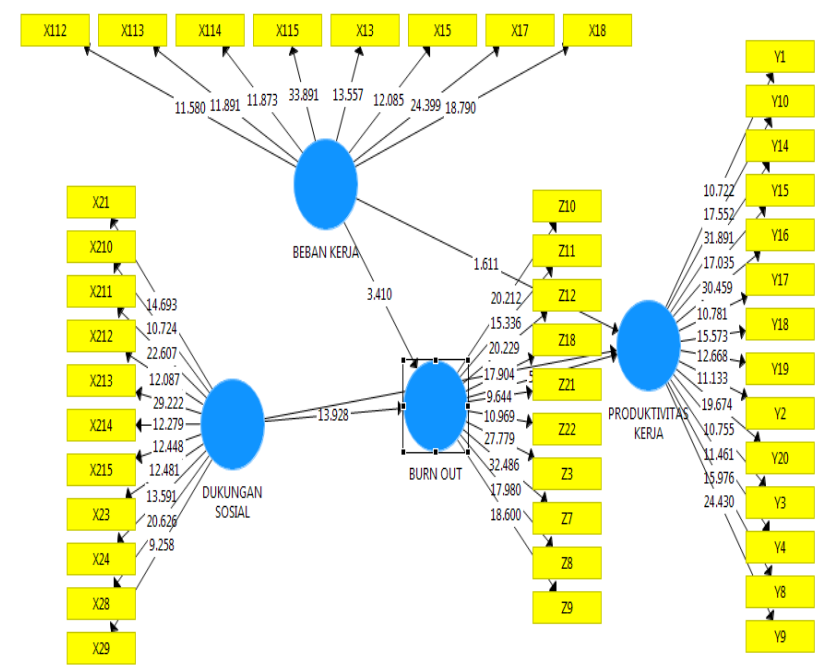

Gambar 1

Hasil kalkulasi model SEM PLS setelah revisi

Untuk nilai loading factor variabel beban kerja, dukungan sosial, burnout, dan produktivitas kerja mempunyai nilai loading factor $>0.6$. Dengan demikian indikator tersebut dinyatakan valid.

Tabel 1

Hasil Pengujian Validitas Konvergen

\begin{tabular}{cc}
\hline \multicolumn{1}{c}{ AVE } & \\
\hline Beban Kerja & 0,608 \\
\hline Dukungan Sosial & 0,631 \\
\hline Burnout & 0,675 \\
\hline Produktivitas Kerja & 0,614 \\
\hline
\end{tabular}

Sumber: Data diolah, 2021

Berdasarkan tabel di atas diketahui bahwa variabel beban kerja, dukungan sosial, burnout, dan produktivitas kerja menghasilkan nilai Average Variance Extracted (AVE) > 0.5. Dengan demikian indikator variabel beban kerja, dukungan sosial, burnout, dan produktivitas kerja dinyatakan valid.

Berdasarkan pengukuran cross loading, dapat diketahui bahwa secara keseluruhan indikator-indikator yang mengukur variabel beban kerja, dukungan sosial, burnout dan produktivitas kerja, menghasilkan loading factor $>$ dibandingkan dengan cross loading pada variabel lainnya. Dengan demikian indikator variabel beban kerja, dukungan sosial, burnout dan produktivitas kerja, dinyatakan valid.

b. Composite reliability dan Cronbach alpha

Hasil perhitungan composite reliability dan cronbach alpha dapat dilihat melalui ringkasan yang disajikan dalam tabel berikut: 
Tabel 2

Hasil Perhitungan Cronbach's Alpha dan Composite Reliability

\begin{tabular}{lcc}
\hline & Cronbach's Alpha & Composite Reliability \\
\hline Beban Kerja & 0.907 & 0.925 \\
\hline Dukungan Sosial & 0.941 & 0.949 \\
\hline Burnout & 0.946 & 0.954 \\
\hline Produktivitas Kerja & 0.951 & 0.957 \\
\hline
\end{tabular}

\section{Sumber: Data diolah, 2021}

Dari tabel di atas, berdasarkan perhitungan Cronbach Alpha dan composite reliability semua indikator yang mengukur variabel beban kerja, dukungan sosial, burnout dan produktivitas kerja, keseluruhannya nilainya $>0,7$ untuk composite reliability dan nilai $>0,6$ untuk cronbach alpha (sesuai dengan kriteria pengujuan), sehingga konstruk tersebut dinyatakan reliabel dinyatakan reliabel.

\section{Deskripsi Hasil Penelitian}

Tabel 3

Deskrptif Statistik

\begin{tabular}{lccccc}
\hline & N & Min & Max & Mean & Std. Devi \\
\hline Workload & 100 & 0.45 & 0.75 & 6.574 & 7.03328 \\
\hline $\begin{array}{l}\text { Social } \\
\text { Support }\end{array}$ & 100 & 0.19 & 0.75 & 6.132 & 10.19297 \\
\hline Burnout & 100 & 0.36 & 1.10 & 8.882 & 14.45605 \\
\hline $\begin{array}{l}\text { Work } \\
\text { Productivity }\end{array}$ & 100 & 0.45 & 1.05 & 8.730 & 13.23868 \\
$\begin{array}{l}\text { Valid N } \\
\text { (Listwise) }\end{array}$ & 100 & & & & \\
\hline
\end{tabular}

Sumber: Data diolah, 2021

Dari tabel 3. Deskriftif statistik diatas didapatkan:

- Beban Kerja, variabel ini menunjukkan nilai minimal: 0.45 dan nilai maksimal: 0.75 dengan rata-rata mayoritas responden menjawab nilai respon terhadap Beban Kerja sebesar 6.574 .

- Dukungan Sosial, variabel ini menunjukkan nilai minimal: 0.19 dan nilai maksimal: 0.75 dengan rata-rata rata-rata mayoritas responden menjawab nilai respon terhadap Dukungan Sosial sebesar 6.132.

- Burnout, variabel ini menunjukkan nilai minimal: 0.36 dan nilai maksimal: 1.10 dengan rata-rata ratarata mayoritas responden menjawab nilai respon terhadap Burnout sebesar 8.882.

Produktivitas Kerja, variabel ini menunjukkan nilai minimal: 0.45 dan nilai maksimal: 1.05 dengan rata-rata mayoritas responden menjawab nilai respon terhadap kepuasan kerja sebesar 8.730 .

\section{c. Three Box Methode}

Deskripsi jawaban responden terhadap variabel- variabel yang diteliti, dilihat dari analisis index jawaban dengan menggunakan kriteria Three Box Methode, sehingga akan dapat diketahui intensitas kondisi masing-masing variabel. Berdasarkan kriteria-kriteria di atas, ditentukan indeks persepi responden terhadap variabel-variabel yang digunakan 
dalam penelitian ini. Rentang kategori three box methode ditetapkan sesuai jumlah responden 100 orang dan skala jawaban dengan skor minimum 1 dan skor maksimum 5, terbagi menjadi 3 rentang, sehingga nilai kategorinya, sebagai berikut:

$$
\begin{aligned}
& 100-233,32=\text { Rendah } \\
& 233,33-366,66=\text { Sedang } \\
& 366,67-500=\text { Tinggi }
\end{aligned}
$$

Tabel 4

Rekapitulasi Three Box Method

\begin{tabular}{clcclc}
\hline \multicolumn{5}{c}{ Posisi Three Box Method } \\
\hline No. & Variabel & Kategori & $\begin{array}{c}\text { Skor } \\
\text { Rata-rata }\end{array}$ & Perilaku & \\
\hline 1. & $\begin{array}{l}\text { Produktivitas } \\
\text { Kerja }\end{array}$ & Sedang & 352,5 & $\begin{array}{l}\text { Kurang Optimal dalam Efektivitas dan } \\
\text { Efesiensi produktivitas kerja staff } \\
\text { keperawatan }\end{array}$ \\
\hline 2. & Beban Kerja & Sedang & 320,0 & $\begin{array}{l}\text { Masih memungkinkan } \\
\text { overload pekerjaan adanya }\end{array}$ \\
\hline 3. & $\begin{array}{l}\text { Dukungan } \\
\text { Sosial }\end{array}$ & Sedang & 343,7 & $\begin{array}{l}\text { Didapatkan kurangnya dukungan } \\
\text { social yang diterima oleh para staff } \\
\text { keperawatan }\end{array}$ \\
\hline 4. & Burnout & Sedang & 324,1 & $\begin{array}{l}\text { Terdapat kondidi burnout yang terjadi } \\
\text { pada beberapa staff keperawatan }\end{array}$ \\
\hline
\end{tabular}

\section{Sumber: Data diolah, 2021}

Dari hasil rekapitulasi Three Box Methode didapatkan bahwa nilai skor rata-rata untuk variabel Produktivitas Kerja adalah 352.5 dan termasuk dalam kategori Sedang, artinya efektivitas dan efisiensi dari produktivitas kerja staff perawat masih belum sepenuhnya optimal. Untuk variabel beban kerja nilai skor rata-ratanya adalah 320 dan termasuk dalam kategori sedang, dalam artian masih mungkin adanya overload dalam hal beban pekerjaan. Pada variabel dukungan sosial memiliki bobot rata-rata sedang, sebesar 343,7 , sehingga dapat diasumsikan masih terdapat kurangnya dukungan sosial yang diterima staff keperawatan. Dan untuk variabel burnout, diketahui bahwa nilai rata-rata skornya adalah 324.1 dan termasuk dalam kategori sedang, artinya dapat diasumsikan masih mungkin timbul suatu kondisi burnout pada staff perawat.

3. Uji Hipotesis Analisis Jalur (Path Analysis)

\section{a. Analisis R-Square}

Berdasarkan hasil pengujian yang telah dilakukan menggunakan PLS dengan bantuan perangkat lunak smart PLS3, diperoleh nilai $\mathrm{R}$-square yaitu:

Tabel 8

Goodness of fit Model (R-Square)

\begin{tabular}{cc}
\hline Variabel & R-Square \\
\hline Burn Out Z & 0.819 \\
\hline Produktivitas Kerja Y & 0.771 \\
\hline
\end{tabular}

R-square Burnout bernilai 0.819. Ini menunjukkan bahwa kontribusi beban kerja dan dukungan sosial terhadap Burnout sebesar $81.9 \%$, sedang sisanya $18.1 \%$ merupakan kontribusi faktor lain yang tidak dibahas dalam penelitian ini. R-square 
produktivitas kerja bernilai 0.771 . Ini menunjukan bahwa kontribusi beban kerja dan dukungan sosial terhadap produktivitas kerja sebesar $77.1 \%$, sisanya $22.9 \%$ merupakan kontribusi faktor lain yang tidak dibahas dalam penelitian ini.

\section{b. $Q$-Square predictive relevance $\left(Q^{2}\right)$}

R Square model PLS dapat dievaluasi dengan melihat Q Square predictive relevance untuk model variabel. Q Square mengukur seberapa baik nilai observasi yang dihasilkan oleh model dan juga estimasi parameternya. Berdasarkan hasil pengolahan data, diperoleh hasil perhitungan.

$$
\begin{aligned}
\mathrm{Q}^{2} & =1-\left[\left(1-\mathrm{R} 1^{2}\right)\left(1-\mathrm{R}^{2}\right)\right] \\
& =1-[(1-0.771)(1-0.819)] \\
& =1-0.041 \\
& =0.959 \text { atau } 95,9 \%
\end{aligned}
$$

Besaran $\mathrm{Q}^{2}$ memiliki nilai dengan rentang $0<\mathrm{Q}^{2}: 0,959<1$, dimana semakin mendekati 1 berarti model semakin baik. Dapat dinyatakan bahwa besarnya keragaman data yang digunakan pada penelitian ini sebesar 95,9\%, sedang sisanya $4,1 \%$ dijelaskan oleh variabel lain diluar penelitian ini.

\section{Pengujian Hipotesis}

a. Pengujian Hipotesis langsung

Kriteria pengujian menyatakan bahwa apabila koefisien jalur nilai $\mathrm{p}$ values $\leq$ alpha 0,05 maka dinyatakan adanya pengaruh dan signifikan variabel eksogen terhadap variabel endogen. Berikut hasil pengujian hipotesis:

Tabel 9

\begin{tabular}{lccccc}
\hline & $\begin{array}{c}\text { Original } \\
\text { Sample }\end{array}$ & $\begin{array}{c}\text { Sample } \\
\text { Mean }\end{array}$ & $\begin{array}{c}\text { Std } \\
\text { Deviasi }\end{array}$ & $\begin{array}{c}\text { T } \\
\text { Statistic }\end{array}$ & $\begin{array}{c}\text { P } \\
\text { Values }\end{array}$ \\
\hline Beban Kerja => Produktivitas & -0.089 & -0.092 & 0.056 & 1.611 & 0.108 \\
\hline Dukungan Sosial => Produktivitas & 0.183 & 0.171 & 0.143 & 1.285 & 0.199 \\
\hline Burnout => Produktivitas & 0.767 & 0.784 & 0.133 & 5.779 & 0.000 \\
\hline Beban Kerja => Burnout & 0.218 & 0.222 & 0.064 & 3.410 & 0.001 \\
\hline Dukungan Sosial => Burnout & 0.763 & 0.762 & 0.055 & 13.928 & 0.000 \\
\hline
\end{tabular}

\section{Sumber: Hasil penelitan yang diolah, 2021}

Berdasarkan data pengujian tabel 9 . dapat dijelaskan hasil sebagai berikut:

H1: Beban Kerja tidak berpengaruh negatif secara langsung terhadap Produktivitas Kerja, sehingga H1 ditolak

H2: Dukungan Sosial tidak berpengaruh negatif secara lagsung terhadap Produktivitas Kerja, sehingga $\mathrm{H} 2$ ditolak

H3: Burnout berpengaruh negatif secara langsung terhadap Produktivitas Kerja, sehingga H3 diterima
H4: Beban Kerja berpengaruh positif secara langsung terhadap Burnout, sehingga $\mathrm{H} 4$ diterima

H5: Dukungan Sosial berpengaruh positif secara langsung terhadap Burnout, sehingga H5 diterima

b. Pengujian Hipotesis Pengaruh Tidak Langsung (variabel mediasi)

Kriteria pengujian menyatakan bahwa apabila koefisien jalur nilai $\mathrm{p}$ values $\leq$ alpha 0,05 artinya terdapat pengaruh variabel eksogen terhadap variabel endogen melalui variabel mediasi. 
Berikut hasil pengujian hipotesis

Tabel 10

pengaruh tidak langsung.

Hasil Pengujian Hipotesis Tidak Langsung

\begin{tabular}{|c|c|c|c|}
\hline & $\begin{array}{c}\text { Indirect } \\
\text { Effect }\end{array}$ & $\begin{array}{c}\mathbf{T} \\
\text { Statistics }\end{array}$ & P Values \\
\hline $\begin{array}{l}\text { Beban Kerja } \Rightarrow \text { Burnout } \Rightarrow> \\
\text { Produktivitas Kerja }\end{array}$ & 0.167 & 2.977 & 0.003 \\
\hline $\begin{array}{l}\text { Dukungan Sosial } \Rightarrow>\text { Burnout } \Rightarrow> \\
\text { Produktivitas Kerja }\end{array}$ & 0.585 & 5.164 & 0.000 \\
\hline
\end{tabular}

Sumber: Hasil penelitian yang diolah, 2021

Berdasarkan pengujian sesuai tabel 10. dapat dijelasakan sebagai berikut:

H6: Beban Kerja memiliki pengaruh terhadap Produktivitas Kerja dengan Burnout sebagai variabel mediasi, sehingga H6 diterima.

H7: Dukungan Sosial memiliki pengaruh terhadap Produktivitas Kerja dengan Burnout sebagai variable mediasi, sehingga $\mathrm{H} 7$ diterima.

Uji Sobel

- Oleh karena t hitung $=15.399>$ dari $t$ tabel dengan tingkat signifikansi 0.05 untuk $\mathrm{N}=100$ : 1.983, maka dapat disimpulkan bahwa koefisien mediasi 0.001259888841 signifikan, berarti terbukti ada pengaruh burnout dalam memediasi hubungan beban kerja terhadap produktivitas kerja.

- Oleh karena t hitung $=3.211>t$ tabel dengan tingkat signifikansi 0.05 untuk $\mathrm{N}=100$ : 1.983 , maka dapat disimpulkan bahwa koefisien mediasi $0.033331447251 \quad$ signifikan, berarti ada pengaruh burnout dalam memediasi hubungan dukungan sosial terhadap produktivitas kerja.

\section{Kesimpulan}

Hasil pengujian menunjukkan bahwa koefisien jalur nilai $p$ value $0,108>$ alpha 0,05 , hal inilah yang menunjukan bahwa Beban kerja tidak berpengaruh secara langsung terhadap Produktivitas kerja.

Hasil penelitian ini sejalan dengan peneliti terdahulu yang menunjukkan bahwa Beban kerja tidak berpengaruh terhadap kinerja pegawai. Dalam artian meskipun beban kerja di RS Medika BSD (saat Pandemi COVID-19) ini cukup tinggi, namun tidak lantas menurunkan produktivitas kerja para perawatnya. Hal ini sesuai dengan teori yang diungkapkan Laeham \& Wexley (1982) yang menyatakan bahwa Produktivitas kerja bukan semata-mata untuk mendapatkan hasil kerja sebanyak-banyaknya, melainkan kualitas kerja yang penting diperhatikan, dengan kata lain produktivitas kerja individu adalah bagaimana seseorang melaksanakan pekerjaannya, bukan berdasarkan beban kerjanya. Dapat juga di katakan bahwa kondisi beban kerja yang berlebihan tidak langsung menimbulkan penurunan produktivitas kerja.

Merujuk pada dimensi Beban kerja, Mental effort load, kategori sedang, ada sebagian perawat menyatakan bahwa mereka merasa kurang beristirahat karena banyaknya beban pekerjaan yang harus dikerjakan (pada unit-unit tertentu, yang memiliki beban kerja yang tinggi, seperti IGD dan Ruang Isolasi), terutama saat Pandemi COVID-19 ini, akibat dari frekwensi datangnya pekerjaan 
meningkat pada unit-unit tersebut, sedangkan unit-unit lain tidak terlalu dirasakan dampaknya. Pada dimensi Psychlogical stress load dengan kategori sedang, ternyata masih ada saja perawat yang tidak mandiri dalam melakukan pekerjaannya, sehingga meminta bantuan rekannya dengan maksud berbagi tanggung jawab untuk mengurangi beban yang dihadapi, misalnya perawat yang bertugas melakukan observasi pada pasien di bangsal, perawat tersebut meminta pendampingan rekan kerjanya, tujuan pekerjaannya tercapai, meskipun dalam variabel produktivitas kerja menjadi tidak efisien. Contoh lain yang berkaitan dengan variabel produktivitas kerja, dimensi Efektivitas dengan kategori sedang, ternyata masih juga ditemukan perawat yang menghindar dari tugas yang sulit (perawat meminta bantuan rekannya), tindakan tersebut membuktikan kurangnya prilaku disiplin dan etika dalam bekerja. Masih dalam dimensi Efektivitas dalam kategori rendah didapatkan bahwa masih ada perawat yang menunda pekerjaan yang seharusnya segera ia lakukan, ini akan menimbulkan penumpukan pekerjaan, sebagai contoh perawat melakukan penundaan retur obat pulang yang seharusnya di lakukan segera setelah dokter menginstruksikan pasien untuk pulang, karena terjadi penundaan maka proses pemulangan pasien juga menjadi terhambat. Prilaku ini termasuk dalam kurangnya disiplin kerja. Sehingga meskipun beban kerja tidak terlalu tinggi namun produktivitas kerja pun tetap rendah.

Hasil pengujian menunjukkan bahwa koefisien jalur nilai $\mathrm{p}$ value $0,199>$ alpha 0,05 , hal inilah yang menunjukan bahwa tidak terdapat pengaruh Dukungan Sosial terhadap Produktivitas Kerja. Penelitian ini tidak sejalan dengan penelitian yang di lakukan oleh Ayu \& Adnyani, (2017); Mulyasih et al., (2019) yang menyatakan, variabel dukungan sosial memberikan pengaruh yang signifikan terhadap produktivitas kerja. Dukungan sosial tidak berpengaruh terhadap Produktivitas kerja secara langsung, sehingga dapat diasumsikan ada atau tidaknya dukungan sosial terhadap perawat (baik dukungan secara profesional dari rekan kerja, maupun dukungan teman dan keluarga) tetap tidak mempengaruhi produktivitas kerja perawat. Hal tersebut mungkin saja terjadi bila perawat tersebut tidak memiliki motivasi, sehingga dukungan sosial yang ada tidak dapat meningkatkan produktivitas kerja (ada faktorfaktor lain yang secara tidak langsung mempengaruhinya), seperti yang diungkapkan oleh Bernard Berendon dan Gary A. Stainer (2001) suatu kondisi mental yang mendorong aktivitas dan memberi energy yang mengarah kepada pencapaian kebutuhan, memberi kepuasan atau mengurangi ketidak seimbangan.

Dalam hal variabel Dukungan Sosial yang dalam Three box Methode menempati kategori sedang pada dimensi Informasi, didapatkan bahwa komunikasi yang terjalin tentang informasi dalam hal pekerjaan kurang diterima dengan baik, ini tentunya dapat memberikan dampak mis-persepsi terutama dalam hal pelayanan pada pasien, contohnya pada saat proses transfer pasien, perawat dari unit pengirim tidak memberikan informasi secara lengkap sehingga ada beberapa pelayanan yang tertunda. Ini merupakan kesalahan Informasi dengan prilaku umpan balik kepada individu. Masih dalam dimensi Informasi, kategori sedang ada beberapa perawat yang merasa atasannya kurang memberikan saran, informasi, solusi berkenaan permasalahan yang ada, misalnya bila ada permasalahan di unit seperti pasien complain, berkenaan dengan handling complain yang cukup pelik, terkadang staff atau kepala ruangan harus berusaha mencari solusi sendiri. Hal tersebut berhubungan dengan prilaku kurangnya saran dan umpan balik yang diberikan atasan kepada bawahan. Dalam variabel produktivitas kerja dengan dimensi Efektivitas, kategori rendah, 
didapatkan masih ada saja para perawat masih sempat mengobrol saat jam dinasnya, hal ini tentunya akan mengurangi tingkat produktivitas kerja akibat dari prilaku kurangnya disiplin dan mengindahkan etika dalam bekerja.

Hasil pengujian menunjukkan bahwa koefisien jalur nilai $p$ value $0,000<$ alpha 0,05 . Hal ini berarti terdapat pengaruh negatif dan signifikan dari Burnout terhadap Produktivitas Kerja. Hasil Penelitian ini sejalan dengan penelitian yang dilakukan oleh Rahmadyah, (2021); Sadry dan Dea, (2017), yang menyatakan bahwa Burnout memiliki pengaruh negatif terhadap kinerja. Hal ini berarti bahwa semakin besar burnout maka semakin rendah produktivitas kerjanya. Hal ini sesuai dengan teori yang diungkapkan Cristina Maslach (1998) Akibat terjadinya suatu burnout bagi suatu organisasi adalah pemberian pelayanan yang berkualitas rendah bagi pelanggan. Burnout dapat menimbulkan kemerosotan kualitas ketelitian terhadap tugas yang diberikan oleh staff. Yang berdampak terhadap penurunan Produktivitas kerja. Yang menjadi perhatian utama adalah burnout akan mengakibatkan ketidak mampuan mencapai standar kerja tertentu, kualitas kerja menjadi buruk, membuat lebih banyak keselahan, menjadi kurang teliti, dan memiliki sedikit kreativitas untuk memecahkan masalah.

Contoh dari kasus yang berhubungan dengan variabel burnout ini dilihat dari dimensi Reduced Personal Accomplishment, dengan kategori rendah, kenyataannya saat pandemi COVID-19 ini masih ada perawat yang merasa stress bila berhubungan langsung dengan pasien, hal ini berkaitan dengan kurangnya kemampuan dan kepercayaan diri dari perawat tersebut, bisa diasumsikan bahwa pengetahuan tentang COVID-19 masih kurang, perawat belum sepenuhnya paham cara penanganan pasien. Ini terkait dengan prilaku rendahnya kompetensi dirinya. Untuk variabel burnout dengan dimensi Depresionalisasi dalam kategori rendah, didapatkan pada kenyataannya masih ada saja perawat yang kurang peduli terhadap kondisi pasiennya, didapatkan pula perawat yang tidak merasa khawatir apabila dengan adanya beban kerja dan berbagai tuntutan yang ada, semakin lama ia berkerja di dunia pelayanan akan menjadi lebih emosional/ menjadi seorang yang pemarah. Hal ini merupakan suatu prilaku yang cenderung meremehkan, tak acuh, tidak perduli dengan orang lain, bersikap kasar, kemungkinannya perawat tidak lagi peduli akan sikap mental atau tempramennya di kemudian hari.

Hasil pengujian menunjukkan bahwa koefisien jalur nilai $\mathrm{p}$ value $0,000<$ alpha 0,05 . Hal ini berarti terdapat pengaruh positif dan signifikan Beban Kerja terhadap Burnout. Penelitian ini sesuai dengan peneliti terdahulu yang dilakukan oleh Alkadash et al., (2020); Donokambey et al., (2018); Maidasari et al., 2018); Khasne et al., (2020); Hardiyono et al., (2020); Morgantini et al., (2020); Rahmadyah, (2021); Eliyana, (2016) yang menunjukkan bahwa beban kerja berpengaruh positif dan signifikan terhadap burnout. Artinya semakin tinggi beban kerja maka akan terjadi kemungkian timbul burnout.

Menurut Harry G Amstrong (1988), ada beberapa faktor yang menyebabkan burnout, salah satunya tekanan pekerjaan yang berhubungan dengan Beban kerja, apabila seorang karyawan menanggung banyak pekerjaan dalam waktu relatif singkat, maka dapat membuat karyawan tertekan dan akan menyebabkan burnout. Pada variabel beban kerja dengan dimensi Psychlogical stress load, kategori sedang, didapatkan masih ada perawat ada yang merasa putus asa menghadapi masalah pekerjaan yang sulit, ini di mungkinkan karena beban kerja yang meningkat di masa pandemi ini, misalnya pekerjaan observasi pada pasien-pasien penderita COVID-19 dengan perburukan, tidak jarang perawat melihat kondisi pasien yang makin parah dan akhirnya pasien 
meninggal, lama kelamaan kondisi ini dapat menimbulkan prilaku yang berdampak frustasi dari perawat terhadap pekerjaannya. Kondisi ini berlanjut dengan variabel burnout dengan dimensi Emotional exhaustion dengan kategori sedang, dimana terdapat kondisi perawat yang mengalami kelelahan secara emosional dengan kondisi pekerjaannya dan menampilkan prilaku frustasi, putus asa dan merasa tertekan terhadap kondisi yang ada. Kembali pada variabel Beban kerja pada dimensi Psychlogical stress load, dengan kategori sedang, masih pula ditemukan perawat tidak dapat mengerjakan pekerjaannya dengan tepat, hal ini bisa disebabkan karena kebingungan, ketidakpahaman serta tekanan psikologis akan kewajiban yang harus dilakukan, tetapi tentunya banyak faktor yang perlu digali kembali apakah kesalahan itu timbul dari dari segi pengetahuan perawat atau dari kesalahan prosedur dalam pelayanan. Misalnya cara pemberian obat perhitungan dosis obatobatan, seringkali masih ditemukan perawat yang tampak bingung tentang pemberian dosis obat atau cairan pasien. Hal ini termasuk prilaku kebingungan terhadap apa yang harus dilakukan.

Hasil pengujian menunjukkan bahwa koefisien jalur nilai $\mathrm{p}$ value $0,000<$ alpha 0,05 . Hal ini berarti terdapat pengaruh negatif dan signifikan Dukungan Sosial terhadap Burnout. Artinya semakin tinggi dukungan sosial yang di dapatkan oleh perawat, maka diharapkan akan mengurangi kondisi burnout. Penelitian ini sejalan dengan penelitian yang dilakukan oleh Ayu dan Adnyani, (2017); M da Costa et al., (2016). Hal ini didukung oleh teori Sarafino dan Smith (2006) yang menyatakan bahwa adanya dukungan sosial membuat individu merasa yakin dirinya dicintai dan dihargai sehingga dapat mengurangi gejala burnout yang dialaminya. Tidak adanya dukungan sosial dapat menimbulkan ketegangan dan meningkatkan terjadinya burnout pada individu. Lee \&
Ashforth (1996), ada beberapa faktor yang menyebabkan burnout, yaitu Tekanan pekerjaan dan Dukungan, seperti Dukungan sosial dari keluarga, teman, kelompok.

Variabel dukungan sosial yang berpengaruh pada burnout dapat dilihat dalam Three Box Methode pada dimensi Emosional kategori rendah, dibuktikan bahwa kenyataannya masih ada saja perawat yang merasa diacuhkan/tidak diperhatikan, baik oleh rekan sekerja maupun oleh atasannya, ini tentunya menuntut suatu prilaku kepedulian dan perhatian yang di berikan pada individu. Sedangkan pada variabel dukungan sosial pada dimensi persahabatan, kategori rendah, ternyata sebagian besar perawat merasa tidak pernah diajak dalam kegiatan sosial di kantor, Corporate Social Responsibility (CSR) biasanya dilakukan oleh para kepala ruangan atau supervisor (dengan maksud agar tidak menganggu pelayanan). Kondisi ini dianggap kurang oleh para staff karena mereka juga menginginkan kontribusi dalam kegiatan sosial sebagai salah satu kontribusi dan bukti kebanggaan mereka terhadap perusahaannya. Prilaku yang terjadi di sini adalah bentuk dari persahabatan, kebersamaan dan aktivitas sosial. Masih pada dimensi persahabatan, dengan kategori sedang, ternyata di lapangan masih saja didapatkan kurangnya kebersamaan yang terjadi di luar RS antara sesma perawat, hal ini mungkin timbul karena kesibukan masing-masing di luar pekerjaannya, padahal kegiatan kebersamaan di luar lingkungan pekerjaan bisa menimbulkan keakraban antara sesama perawat. Kondisi ini tentunya tidak mungkin dikontrol oleh manajemen karena kondisi yang terjadi di luar kegiatan RS merupakan hak pribadi perawat tersebut. Prilaku yang ini termasuk kedalam persahabatan, kebersamaan dan kesediaan untuk mengakrabkan diri.

Hasil pengujian menunjukkan bahwa koefisien jalur nilai $p$ value $0,003<$ alpha 0,05 . Selain dari itu sesuai hasil uji Sobel didapatkan nilai t hitung $15.399>$ dari t tabel 
1.983, maka dapat disimpulkan bahwa koefisien mediasi signifikan, sehingga berarti ada pengaruh burnout dalam memediasi hubungan beban kerja terhadap produktivitas kerja. Penelitian ini didukung oleh Efendi, (2009), yang menyatakan bahwa beban kerja yang terlalu berlebihan akan menimbulkan kelelahan baik fisik atau mental dan reaksireaksi emosional seperti sakit kepala, gangguan pencernaan dan mudah marah. Beban kerja yang berlebihan atau rendah dapat menimbulkan stress kerja. Hampir setiap beban kerja dapat mengakibatkan timbulnya burnout, tergantung bagaimana reaksi pekerja itu sendiri menghadapinya (Fraser, 1992).

Tingginya beban kerja yang mempengaruhi burnout akan berdampak pada menurunnya Produktivitas kerja yang ditunjukkan dengan rata-rata nilai skor jawaban untuk variabel Produktivitas diperoleh sebesar 352.5 yang berada dalam kategori sedang. Pada variabel burnout dengan dimensi Reduced Personal Accomplishment, dengan kategori sedang, didapatkan suatu kondisi dimana perawat merasa bahwa pekerjaan yang mereka lakukan kurang maksimal sehingga ada pasien yang tidak merasa puas dan menyalahkannya atas pelayanannya. Perawat menyadari bahwa pekerjaan yang ia lakukan tidak maksimal, ini bisa terjadi karena ketidakmampuan perawat yang bersangkutan dan merupakan prilaku perasaan tidak mampu menghadapi tuntutan pekerjaan. Masih pada variabel burnout dengan dimensi Emotional Exhaustion, dengan kategori sedang, timbul suatu kondisi dimana ada perawat yang mengalami kelelahan emosional dengan kondisi pekerjaannya (beban kerja yang tinggi), prilaku ini dapat di kategorikan dalam suatu bentuk frustasi, putus asa dan merasa tertekan terhadap kondisi yang ada. Bila ini dibiarkan berlarut-larut tentunya akan menimbulkan burnout dan akan menurunkan produktivitas kerja.
Hasil pengujian menunjukkan bahwa koefisien jalur nilai $\mathrm{p}$ value $0,000<$ alpha 0,05 . Selain dari itu sesuai hasil uji Sobel didapatkan karena $\mathrm{t}$ hitung $3.211>\mathrm{t}$ tabel 1.983, maka dapat disimpulkan bahwa koefisien mediasi signifikan dan terbukti dengan uji sobel ada pengaruh burnout dalam memediasi hubungan dukungan sosial terhadap produktivitas kerja.

Dukungan sosial keluarga dan perhatian orang lain dapat membuat orang mampu bertahan terhadap tekanan yang menimbulkan burnout. Burnout akan berdampak negatif pada individu dan perusahaan, antara lain menyebabkan rendahnya atau menurunnya job performance. Produktivitas merupakan konsep yang menghubungkan hasil dengan alat-alat yang menghasilkan hasil tersebut, teori ini yang di sampaikan oleh George Kuper (1975), sejauh mana sumber-sumberdaya disertakan dan dipadukan dalam organisasi dan digunakan untuk mencapai seperangkat hasil. Sumber daya tersebut salah satunya bisa di dapatkan dari suatu dukungan (bisa berasal dari dukungan sosial). Sebagai contoh dukungan sosial yang mempengaruhi produktivitas kerja dengan kondisi burnout yang terjadi di masa pandemi COVID-19 saat ini dapat di lihat dalam Three box methode pada variabel dukungan sosial dimensi Emosional dengan kategori rendah, karena masih ada saja perawat yang merasa di acuhkan dilingkungan kerjanya (baik oleh sesama staff maupun atasannya). Dukungan dari atasan (Kabid keperawatan) dengan cara pembagian atau pertukaran dinas dari unit-unit dengan beban kerja tinggi (Ruang perawatan isolasi) ke unit rawat jalan (poliklinik), selain itu atasan dapat bertanya pada bawahannya perasaan yang mereka rasakan saat ini (kekhawatiran atau hal-hal yang mengganjal), hal ini tentunya akan membesarkan hati para staff dan ada rasa diperhatikan. Prilaku ini sesuai dengan dimensi Emosional dengan 
prilaku kepedulian dan perhatian yang diberikan pada individu tersebut

\section{BIBLIOGRAFI}

Aini, F., \& Purwaningsih, P. (2013). Hubungan Antara Beban Kerja Dengan Stres Kerja Perawat Di Instalasi Gawat Darurat Rsud Kabupaten Semarang. Jurnal Manajemen Keperawatan, 1(1). Google Scholar

Bakker, A. B., Demerouti, E., \& Sanz-Vergel, A. I. (2014). Burnout And Work Engagement: The Jd-R Approach. Annu. Rev. Organ. Psychol. Organ. Behav., 1(1), 389-411. Google Scholar

Dong, L., \& Bouey, J. (2020). Public Mental Health Crisis During Covid-19 Pandemic, China. Emerging Infectious Diseases, 26(7), 1616. Google Scholar

Ghozali, I. (2018). Aplikasi Analisis Multivariate Dengan Program Ibm Spss 25, Edisi Kesembilan. Semarang: Penerbit Undip. Google Scholar

Hardiyono, H., Aiyul, I., Ifah, F., Wahdaniah, W., \& Reni, F. (2020). Effect Covid-19: Burnout On Nurse. Revista Especial, 41(42), 11-18. Google Scholar

Humas, F. (2020). 83\% Tenaga Kesehatan Indonesia Mengalami Burnout Syndrome Derajat Sedang Dan Berat Selama Masa Pandemi Covid-19. Fakultas Kedokteran Universitas Indonesia. Https://Fk. Ui. Ac. Id/Berita/83-Tenaga-

Kesehatanindonesia-Mengalami-

Burnout-Syndrome-Derajat-SedangdanBerat-Selama-Masa-Pandemi-Covid-19. Html. Google Scholar

Lenny Hasan, L. H., \& Febriani, F. (2016). Analisis Motivasi Pengrajin Sulaman Benang Emas Di Kota Padang. Manajemen Dan Kewirausahaan, 7(2), 42-53. Google Scholar
Maharja, R. (2015). Analisis Tingkat Kelelahan Kerja Berdasarkan Beban Kerja Fisik Perawat Di Instalasi Rawat Inap Rsu Haji Surabaya. The Indonesian Journal Of Occupational Safety And Health, 4(1), 93-102. Google Scholar

Maslach, C., \& Jackson, S. E. (1981). The Measurement Of Experienced Burnout. Journal Of Organizational Behavior, 2(2), 99-113. Google Scholar

Organization, W. H. (2019). Global Status Report On Alcohol And Health 2018. World Health Organization. Google Scholar

Papdi, C., Abrahám, E., Joseph, M. P., Popescu, C., Koncz, C., \& Szabados, L. (2008). Functional Identification Of Arabidopsis Stress Regulatory Genes Using The Controlled Cdna Overexpression System. Plant Physiology, 147(2), 528-542. Google Scholar

Pardo, A., Mespouille, L., Blankert, B., Trouillas, P., Surin, M., Dubois, P., \& Duez, P. (2014). Quercetin-Imprinted Chromatographic Sorbents Revisited: Optimization Of Synthesis And Rebinding Protocols For Application To Natural Resources. Journal Of Chromatography A, 1364, 128-139. Google Scholar

Schultz, D. P., \& Schultz, S. E. (2020). Psychology And Work Today: An Introduction To Industrial And Organizational Psychology. Routledge. Google Scholar

Siagian, S. P. (2001). Audit Manajemen. Google Scholar

Smith, A. P., \& Smith, H. N. (2017). Workload, Fatigue And Performance In The Rail Industry. International Symposium On Human Mental Workload: Models And Applications, 251-263. Google Scholar 
Yulianto, S., Apriyadi, R. K., Aprilyanto, A., Winugroho, T., Ponangsera, I. S., \& Wilopo, W. (2021). Histori Bencana Dan Penanggulangannya Di Indonesia Ditinjau Dari Perspektif Keamanan Nasional. Pendipa Journal Of Science Education, 5(2), 180-187. Google Scholar

\section{Copyright holder:}

Yanna Dwi Saptarani, Agusdini Banun Saptaningsih, R. Fresly Hutapea (2022)

\section{First publication right:}

Jurnal Health Sains

This article is licensed under: 4(1), 21-28. Google Scholar Kerja Dan Lingkungan Kerja Dengan Stres Pada Perawat Instalasi Bedah Sentral. Journals Of Ners Community, 